Bartın Üniversitesi

Eğitim Fakültesi Dergisi

Cilt 6, Sayı 1, s. 48-67, Şubat 2017

BARTIN - TÜRKIYE

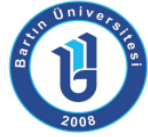

ISSN: 1308-7177
Bartin University

Journal of Faculty of Education

Volume 6, Issue 1, p. 48-67, February 2017

BARTIN - TURKEY

\title{
Öğretmen Adaylarının Matematiksel Örnekleri Algılayışları Üzerine Bir Metafor Analizi
}

Yasemin SAĞLAM KAYA, Yrd. Doç. Dr., Hacettepe Üniversitesi Eğitim Fakültesi, ysaglam@hacettepe.edu.tr

Öz: Örnekler, matematik öğretiminde kullanılan önemli araçlardan biridir. Ancak yapılan araştırmalar incelendiğinde, matematik öğretmen adaylarının, farklı türdeki matematiksel örnekleri nasıl algıladığı, öğretmen ve öğrenci tarafından verilen örneklerin hangi amaçlara hizmet ettiğine dair bir araştırmaya rastlanmamıştır. Öğretmen adaylarının matematiksel örnekleri algılayış biçimleri, ilerideki mesleki hayatlarında matematiksel örnekleri nasıl kullanacakları hakkında fikir verebilir. Bu nedenle bu çalışmanın amacı, matematik öğretmen adaylarının farklı tür matematiksel örnekler ile öğretmen ve öğrenci tarafından verilen örnekleri nasıl algıladıklarını metafor analizi ile incelemektir. Çalışmanın katıımcılarını 190 matematik öğretmen adayı oluşturmaktadır. Veri toplama aracında katılımcılardan; "Matematikteki görsel örnekler... gibidir, çünkü..." ; "Matematikteki cebirsel örnekler... gibidir, çünkü..." ; "Matematik dersinde öğretmenin verdiği örnekler gibidir, çünkü..."; "Matematik dersinde öğrencinin verdiği örnekler... gibidir, çünkü..." ifadelerini tamamlamaları istenmiş ve elde edilen veriler içerik analizine tabi tutulmuştur. Çalışmadan elde edilen verilerin güvenirliğini sağlamak amacıyla 11 katılımcı ile yarı yapılandırılmış görüşme yapılmıştır. Ayrıca görüşmeler yoluyla öğretmen adaylarının örnekleri algılayış biçimlerine ilişkin derinlemesine veri elde edilmiştir.

Anahtar Kelimeler: matematiksel örnekler, metafor analizi, öğretmen adayları

\section{A Metaphor Analysis on Preservice Teachers' Conception of Mathematical Examples}

\begin{abstract}
Examples are one of the important tools used in mathematics teaching. However, there isn't any research which grasps how preservice teachers perceive the mathematical examples or what they think about the purpose of examples which were given by teachers or students. Conception of preservice teachers on examples can give clues about the use of examples in their future profession. To reveal the opinions of preservice teachers whether examples can be generated by students, is important to ensure that teacher training programs place emphasize on this issue. So, the purpose of the study is to investigate the preservice teachers' conception of different kinds of mathematical examples and examples given by teachers or generated by students with metaphor analysis. Participants of the study consist of 190 preservice mathematics teachers. Data collection tool is included four uncompleted sentences in the form: "Visual examples in mathematics are like..., becaus..."; "algebraic examples in mathematics are like..., because..."; "Examples given by teacher in mathematics are like..., because......"; "Examples given by students in mathematics are like..., because...". Participants are asked to complete these sentences. Obtained data were analyzed by using content analysis. To ensure the reliability of the data interviews were conducted with 11 of participants, so classification and thematization of metaphors were checked. In addition, through the interviews in-depth information was obtained on perceptions of preservice teachers with respect to mathematical examples.
\end{abstract}

Key Words: Mathematical examples, metaphor analysis, preservice teachers 


\section{GíRiş}

\subsection{Matematiksel Örnekler}

Örnekler hangi alanda olursa olsun, pedagojik açıdan eğitim faaliyetlerinin vazgeçilmezleri arasındadır. Matematik özelinde düşünüldüğünde örnekler, özellikle genelleme, soyutlama ve analojik düşünmede (Zodik ve Zaslavsky, 2009) önemli bir role sahiptir. Bu rolün en önemli özelliği birçok araştırmacı (örn. Peled \& Zaslavsky, 1997) tarafından da belirtildiği gibi öğretmen ve öğrenci arasında bir iletişim aracı olmasıdır. Özellikle matematiksel kavramların öğretiminde örneklerden yararlanmak, matematik öğretiminin ayrılmaz bir parçasıdır (Abdul-Rahman, 2005). Çünkü örnekler, hem iyi bir açıklamanın temel unsuru hem de iyi bir öğretim için yapı taşıdır (Leinhart, 2001). Örneklerin bu özelliğinden yola çıkararak hem öğrenciler hem de öğretmenler matematiksel örnekleri farklı anlamlarda (açıklama, motivasyon, sezgi oluşturma vb.) kullanabilmektedirler. Bunun en büyük nedeni, örneklerin matematik öğretiminde geniş bir kullanım alanının var olmasıdır. Bu nedenle örneklerin kullanımı ile ilgili olarak yapılacak ilk ayrımlardan biri, bir kavramın örneği (üçgenler, polinomlar vb.) ile bir prosedürün uygulanmasının örneğidir (bir üçgenin alanının bulunması, bir polinomun köklerinin bulunması) (Bills, Dreyfus, Mason, Tsamir, Watson, Zaslavsky, 2006). Bills ve diğerleri (2006) bu ikincisi için yeni bir ayrım daha yapmaktadır: Öğretmen, bir ders kitabı yazarı ya da bir programcı tarafından, bir prosedürün uygulandığı, çoğunlukla bir takım açıklamalar ve yorumlar içeren, "çalışılmış örnekler" (worked examples) ve öğrencilerin tamamlaması için ayarlanmış "alıştırmalar". Aslında pek çok araştırmacı matematiksel örneklerin bir takım özelliklerini göz önünde bulundurarak farklı gruplamalar yapmışlardır. Sınıf içinde kullanım amacına göre başlangıç örnekleri (bir konu için motivasyon ve başlangıç amacıyla kullanılan), referans örnekler (bilgilendirmek ve sezgi oluşturmak için), model veya genel örnekler (bir kavramın veya bir prosedürün örneği), ters örnekler (bir sava karşı çıkmak için verilen bir örnek, bir prosedürün örneği veya bir kanıtın parçası), örnek olmayan durumlar (ayrımları ortaya çıkarmak veya bir kavram için temel olan ve olmayan özellikler arasındaki farklara dikkat çekmek yani sınırları belirginleştirmek için verilen örnekler); özel, yarı genel ve genel örnekler (örneklerin açıklama güçlerine göre) gibi kategoriler belirlenmiştir (Zaskis ve Leikin, 2008; Michener, 1978; Goldenberg ve Mason, 2008; Bills ve diğerleri, 2006; Peled ve Zaslavsky, 1997). Her ne kadar bu şekilde sınıflamalar yapılsa da herhangi bir gruba giren bir örneği diğerlerinden kesin çizgilerle ayırmak mümkün değildir. Bazen bir sınıflamadaki bir örneği, farklı özelliklerden yararlanılarak başka bir sınıflamaya yerleştirmemiz de mümkün olabilmektedir.

Örneklerin sınıf içinde farklı amaçlarda kullanılıyor oluşu ve farklı özelliklere sahip oluşu öğretmenlerin ve öğrencilerin örneklere yönelik algılarında da farklılıklar oluşmasına neden olabilmektedir. Örneklerin gösterimleri ve öğretmenlerin, öğrencilerin dikkatini istenen noktaya toplamalarına yardımcı olmaya çalışması, aslında öğrenenlerin neyi fark ettiğine ve çoğunlukla onların matematiksel anlamalarına bağlıdır (Bills ve diğerleri, 2006). Bu da genellikle öğrenenlerin matematikle ilgili önceki deneyimleriyle şekillenmektedir. Skemp (1971) bu durumun özel bir halini parazit (noise) kavramıyla açıklamaktadır. Bu kavram kısaca öğretmenin bir örnekte öğrencilere anlatmak istediği özellik dışında, öğrencinin dikkatini çeken ve anlatılmak istenen durum için önemli olmayan özellikleri ifade etmektedir. Bu nedenle, öğretmenler örnekleri sınıf içinde kullanırken dikkatli olmak zorundadırlar.

Zaslavsky (2010) örneklerin sınıf içinde kullanımı sırasında, bir diğer önemli faktörün gösterim olduğuna, bir parabol denkleminin üç farklı sunumuyla dikkat çekmektedir. (i) $y=(x+$ 1) $(x-3)$; (ii) $y=(x-1)^{2}-4$; (iii) $y=x^{2}-2 x-3$ örneklerinde olduğu gibi üç farklı formatta verilen ikinci dereceden bir fonksiyonun her bir yazımında bazı özellikler görünür hale gelmekte (kökler, tepe noktası ve fonksiyonun grafiğinin y-eksenin kestiği nokta) bazı özellikler 
gizlenmektedir. Sadece cebirsel olarak farklı biçimde verilen bir örneğin gösterimiyle oluşan öğretimsel farklııklar, gösterimlerin de değişmesiyle (görsel veya cebirsel gibi) farklı boyutlar kazanabilir. Dolayısıyla öğretmen bu gösterimlerden hangisini kullanacağına karar verirken bunları göz önünde bulundurması gerekmektedir. Örneklerin seçimi ve ele alış biçimi öğrencilerin öğrenmesini zorlaştırma ve kolaylaştırma potansiyeline sahip olduğundan, bu durum öğretmenlere uğraştırıcı bir sorumluluk vermekte ve örneklerin birçok özelliğini düşündürmeyi gerektirmektedir (Zaslavsky ve Zodik, 2007). Ancak öğretmenlerin sınıf içinde kullandıkları örnekleri seçerken buna ne kadar dikkat ettiği ile ilgili bir araştırma henüz yapılmamıştır. Bunun yanında öğretmenlerin örnekleri ele alış biçimi onların matematiksel ve pedagojik bilgileri hakkında da bilgi vermektedir (Zodik ve Zaslavsky, 2009). Görüldüğü gibi örnekler, matematik öğrenmekte ve öğretmekte oldukça kritik bir role sahiptir. Buna rağmen, öğretmenlerin (dolayısıyla öğretmen adaylarının) örnekleri ele alış biçimleri üzerine sınırlı sayıda araştırma bulunmaktadır (Zaslavsky, 2010).

\subsection{Metafor}

Metafor, bir bireyin soyut, karmaşık veya kuramsal bir olguyu anlamada ve açıklamada kullandığı güçlü bir zihinsel yapı olarak açıklanmaktadır (Saban, Koçbeker ve Saban, 2006). Başka bir deyişle metafor somut, daha tanıdık ve görülebilir şeylerle soyut şeyler arasında kurulan mecazi bağ olarak da açıklanabilir (Saban, 2004). Bu bağlamda metaforlar bir başlangıç veya kaynak alandan (bizim için tanıdık olan) bir nihai veya hedef alana (bizim için yeni veya soyut olan) kavramsal bir ilişki kurarlar (Font, Bolite ve Acevedo, 2010). 'Matematik bir merdivendir' metaforunda olduğu gibi daha soyut bir kavram olan matematik daha somut olan bir kavramla ilişkilendirilerek ifade edilmiştir. Bu metaforda kurulan ilişkide, matematiğin yığılmalı bir bilim dalı olduğu, en temel kavramlarla başlanarak daha karmaşık kavramlara ilerlenebileceği sonucu çıkarılabilir. Ancak farklı kişiler tarafından farklı bağlantılar kurulabilir. Bu noktada kişilerin bakış açıları önem kazanmaktadır. Yani bize bir terimin bir boyutunu diğerine göre kavrama imkanı veren sistematiklik, kavramın diğer boyutunu zorunlu olarak gizler ve dolayısıyla kavramın bir boyutu üzerine odaklanma imkanı veren metaforik kavram, bizi kavramın bu metaforlarla uyuşmayan diğer boyutları üzerinde odaklanmaktan alıkoyabilir (Lakoff ve Johnson, 2015). Aslında metaforlar tek yönlü ve sistemik olarak ifade edilebilir ve tek yönlü metaforlarda bağlantı tek şekilde kurulurken, sistemik metaforlar, hedef alanını kaynak alan türünden anlamamızın bir sonucu olarak bizim yeni sistemler kurmamızı sağlar (Font, Bolite ve Acevedo, 2010).

İnsanın düşünme süreci büyük ölçüde metaforiktir (Lakoff ve Johnson, 2015). Kavramsal metafor teorisi aslında nasıl düşündüğümüzü anlama yönünde yapılan bir girişimdir ve temelinde beynimizin şekillendirilmiş bir yapıya sahip olması vardır (Aubry, 2009). Yani olaylar hakkındaki düşüncelerimiz, daha önce yaşadığımız deneyimler, içinde bulunduğumuz kültürün etkisiyle şekillenen beynimizden gelmektedir (Aubry, 2009). Eğitimde de dâhil olmak üzere diğer bilim alanlarında çalışan araştırmacılar veya uygulama alanında çalışanlar farkında olmadan alanlarında ortaya çıkan metaforik örüntüler ve imgeler tarafından yönlendirilmektedir (Martinez, Sauleda ve Huber, 2001). Genel olarak eğitim alanında metaforlarla ilgili yapılan araştırmalar incelendiğinde en çok öğrenme-öğretme, öğrenciöğretmen, okul gibi kavramlarının farklı gruplardaki (öğretmen, öğretmen adayı) metaforik algılarının incelendiği gözlenmektedir (örneğin, Saban, 2009; Leavy, McSorley ve Bote, 2007; Martinez, Sauleda ve Huber, 2001; Bullough, 1991, Cerit, 2006; Güler, Öçal ve Akgün, 2011 ).

Metaforlar farklı duyular arasında ilişkiler kurduklarından insanlara, matematiksel kavramlar için anlamlar oluşturmada da gereklidir (Font, Bolite ve Acevedo, 2010). Bu nedenle matematik eğitiminde yapılan çalışmalarda metaforlar sıklıkla kullanılmaktadır ( örn. Chapman, 1997; Font, Bolite ve Acevedo, 2010; Font, Godino, Planas ve Acevedo, 2010; Uygun, Gökkurt, 
Usta, 2016). Font, Bolite ve Acevedo (2010) fonksiyonların grafiksel gösteriminin öğretimi sürecinde öğretmenlerin kullandığı metaforları incelemişlerdir. Başka bir araştırmada ise Ju ve Kwon (2004) öğrencilerin diferensiyel denklemlere ilişkin kavramsal modellerinin belirlemek için metaforların öğrenciler tarafından nasıl kullanıldığı, metaforların karakteristikleri ve metafor kullanımlarındaki örüntüleri araştırmışlardır. Lakoff ve Núñez (2010) matematik bağlamında iki tür kavramsal metafordan bahsetmektedir (akt. Font, Bolite ve Acevedo, 2010;): Temel metaforlar ve bağlantı metaforları. Temel metaforlar matematik içindeki bir kavramı matematik dışındaki bir kavram ile ilişkilendirirken, bağlantı metaforları, ilişkilendirmeyi matematik içinde sürdürür ve matematik içindeki özellikleri birbiri ile değiştirir.

Öğretmen eğitimi programlarının en önemli amaçlarından biri öğretmen adaylarını alanlarında gerekli olan bilgi ve becerilerle donatmaktır. Ancak bunu yaparken farkında olunması gereken noktalardan biri öğretmen adaylarının da tıpkı diğer öğrenciler gibi sınıflara farklı deneyimlerle geldiğidir. Dolayısıyla öğretmen adaylarına öğretmenlik becerilere kazandırılmak istenirken var olan varsayımları, deneyimleri ve algılarının ortaya çıkarılması gerekmektedir. Bu bağlamda metaforlar, açık veya bilinçli olmayan bir şekilde sahip olunan fikirler hakkında iç görü sağlayacak uyum ve iç tutarlılığa sahiptir (Leavy, McSorley ve Bote, 2007).

Bu çalışmanın amacı öğretmen adaylarının matematiksel örnekler kapsamında sahip oldukları metaforları belirleyerek sınıfta örnek kullanımına ilişkin algılarını ortaya çıkarmaktır. Daha önce birçok çalışmada (örn. Thompson 1992; Saglam, 2014) belirtildiği gibi öğretmenlerin sahip oldukları duyuşsal özellikler, inanışlar, deneyimler ve algılar onların sınıf içi etkinliklerini etkileme potansiyeline sahiptir. Dolayısıyla öğretmen adaylarının bu tür özelliklerinin ortaya çıkarılması, öğretmen eğitimi programlarının içeriğinin değişen şartlar doğrultusunda yeniden düzenlenmesi için fırsat oluşturacaktır.

\section{YÖNTEM}

Bu araştırma var olan durumu olduğu gibi betimlemeye yönelik betimsel bir çalışmadır. Betimsel araştırmalarda, bireylerin çalışılan kavram ya da duruma ilişkin olarak tutum veya davranışlarının açığa çıkarııması amaçlanır (Creswell, 2008).

\section{1. Çalışma Grubu}

Çalışmanın katılımcılarını bir devlet üniversitenin bir (13 katılımcı), iki (19 katıımcı), üç (78 katılımcı), dört (63 katılımcı) ve beşinci (17 katılımcı) sınıfında öğrenim görmekte olan 190 matematik öğretmen adayları oluşturmaktadır.

\subsection{Veri Toplama Araçları ve Verilerin Analizi}

Çalışmada veri toplamak amacıyla kullanılan envanterde katılımcılardan; "Matematikteki görsel örnekler... gibidir, çünkü ..." , "Matematikteki cebirsel örnekler... gibidir, çünkü ..." , "Matematik dersinde öğretmenin verdiği örnekler... gibidir, çünkü..." , "Matematik dersinde öğrencinin verdiği örnekler... gibidir, çünkü..." ifadelerini tamamlamaları istenmiştir. Öğretmen adaylarının farklı tür matematiksel örnekler hakkındaki görüşlerini belirlemek amacı ile ürettikleri metaforlar içerik analizi ile analiz edilmiştir. Verilerin analizi için sırasıyla aşağıdaki adımlar izlenmiştir.

1. Adlandırma Aşaması: Öğretmen adayları tarafından üretilen metaforların geçici bir listesi yapılmıştır.

2. Tasnif Etme ve Eleme Aşaması: Bu aşamada, "metafor analizi" (Moser, 2000) ve içerik analizi teknikleri kullanılarak, her metafor parçalarına ayrıştırılmış ve diğer metaforlarla olan benzerlikleri veya ortak özellikleri bakımından analiz edilmiştir. Elde edilen verilerde, 
tamamlanmamış bölümleri olan veya metafor ifade etmeyen cümleler (öğretmenin verdiği örnek anlamlandırıcı gibidir; çünkü kavram yanılgısına düşmemizi engeller gibi) analize dahil edilmemiştir.

3. Kategori Geliştirme Aşaması: Bu aşamada metaforlar, bireysel metafor ifadelerinden yola çıkılarak sahip oldukları ortak özellikleri bakımından kavramsal kategoriler altında toplanmıştır. Herhangi bir temayla uymayan aykırı metaforlar ise bağımsız metafor kategorisinde değerlendirilmiş ve bunların sayıları her bir başlık için ayrıca belirlenmiştir.

"Toplanan verilerin ayrıntılı olarak rapor edilmesi ve araştırmacıların sonuçlara nasıl ulaştıklarını ayrıntılı olarak açıklaması nitel bir araştırmada geçerliğin önemli ölçütleri arasında yer almaktadır." (Yıldırım ve Şimşek, 2005, s. 257). Bu nedenle çalışmanın her bir aşaması ayrıntılı bir şekilde rapor edilmiştir. Makalenin (iç) güvenirliğinin kontrolü için, öncelikle elde edilen verilerin \% 25 'i farklı bir araştırmacı tarafından tekrar kodlanmıştır. Kodlayıcılar arası güvenirlik için tekrar kodlanması gereken veri, tüm veri setinin \%10'undan az olmamalıdır (Nuendorf, 2002). Tekrar kodlanan veriler için SPSS 22 paket programı kullanılarak Cohen's Kappa katsayısı hesaplanmış ve 0,75 bulunmuştur. Güvenirliğin 0,70 ve üzeri olması kodlamanın güvenilir olduğunun bir göstergesidir (Miles ve Huberman, 1994). Bunun yanında metaforların belirlenmesi, kategorilerin oluşturulması aşaması için katılımcılardan 11 tanesi ile görüşme yapılmıştır. Görüşmeler, öncelikle metaforların araştırmacı tarafından uygun şekilde kategorilendirilmesinde kullanılmıştır. Ayrıca bu görüşmeler sırasında öğretmen adaylarının örnekleri sınıf içinde nasıl ve hangi amaçla kullanmayı planladığı sorulmuş, öğretmenlerin ve öğrencilerin verdiği örneklerin kavramsal anlama ve öğrenilenlerin kalıcılığı anlamında değerlendirmeleri istenmiş böylece hem metafor analizi ile elde edilen veriler desteklenmiş hem de çalışmanın amaçlarından biri olan örneklerin algılama şekilleri daha net bir şekilde ortaya çıkarılmıştır. Görüşmeler sırasında ses kaydı alınmış, elde edilen veriler yazılı metne dönüştürülmüş ve içerik analizi kullanılarak analiz edilmiştir.

\section{BULGULAR}

Veri toplama aracında yer alan ve öğretmen adayları tarafından tamamlanması beklenen cümlelerden elde edilen veriler görsel örnek, cebirsel örnek, öğretmenin verdiği örnek ve öğrencinin verdiği örnek başlıkları altında incelenmiştir. Her bir başlık için 10'un altında metafordan oluşan alt başıklar tek bir başlık altında toplanmıştır. Temaların sıralanışı, barındırdığı metafor sayısına göre çoktan aza doğrudur. Görüşmeler sırasında öğretmen adaylarının örnekleri sınıf içinde kullanımlarına yönelik görüşleri ayrı bir başlık altında incelenmiştir.

\subsection{Görsel Örnekler}

Çalışmanın bu bölümünü öğretmen adaylarının veri toplama aracının birinci sorusu olan "Matematikteki görsel örnekler... gibidir; çünkü..." cümlesinin tamamlayarak oluşturdukları verilerin analizi oluşturmaktadır. Öğretmen adaylarının belirtilen cümleyi tamamlamasıyla oluşturulan kodlar yedi tema altında toplanmaktadır.

Soyut kavramları somutlaştıır: Bu tema altında 79 kod toplanmıştır. Öğretmen adayları görsel örneklerin, matematikteki soyut kavramların öğrenciler tarafından somutlaştırılmasına katkısı olduğunu belirtmişlerdir. Bu sayede soyut kavramların ne işe yaradığının daha net anlaşıldığı ya da anlatıldığında anlaşılmayan kavramların görsel olarak verildiğinde daha iyi anlaşılabileceğini düşünmektedirler. Bu tema altında toplanan kodlardan en çok tekrar edenlere örnek olarak resim (15 defa), model (5), harita (5) verilebilir. Öğretmen adaylarının yazdıkları cümlelerden bazı örnekler aşağıdaki gibidir.

“Matematikteki görsel örnekler resim gibidir, çünkü anlatılanları görsel olarak betimler" 
“Matematikteki görsel örnekler harita gibidir, çünkü yolu daha iyi kafamızda canlandırmamız için haritaya bakmamı gerekir"

"Matematikteki görsel örnekler deney gibidir, çünkü hayal edemediği şeyleri görerek zihninde daha iyi oturtmasını sağlar"

Matematiği zevkli hale getirir: Bu tema altında 28 kod toplanmıştır. Öğretmen adayları görsel örnekler sayesinde matematiğin daha zevkli hale geldiğini düşünmektedir. Bu tema altında toplanan bazı kodlar şeker (2), meyve (2), karnaval (2) şeklindedir. Öğretmen adaylarının düşüncelerini belirttiği bazı cümleler ise şöyledir:

“Matematikteki görsel örnekler yemek baharatı gibidir, çünkü baharat yemeğin lezzetlenmesini sağlar, görsel örneklerde konunun tadını, işlevselliğini ortaya çıkararak konunun iştah verici olmasını sağlar"

"Matematikteki görsel örnekler çayın şekeri gibidir, çünkü şeker olmadığında çay tatsız ve anlamsızdır, şekerle daha tüketilebilir bir hal alır"

"Matematikteki görsel örnekler renkler gibidir, çünkü matematikte görsellik olmazsa kuru ve zevksiz kalır. Renklerin hayatı zenginleştirmesi gibi görsel örnekler de matematiği zenginleştirir."

Konuyu anlamamızı kolaylaştırır: Bu tema altında 24 kod toplanmıştır. Öğretmen adayları görsel örnekler sayesinde öğrenilen konuların daha kolay anlaşıldığını düşünmektedir. Bazen tek bir görselin anlatılmak isteneni vermek için yeterli olabileceğini belirtmişlerdir. Verilen metaforlardan bazıları ilaç (3), ayna (3), tablo'dur (3). Bu metaforları oluşturan örnek cümleler aşağıdaki gibidir.

“Matematikteki görsel örnekler ışık gibidir, çünkü öğrencinin konuyu anlamasını sağlar”

"Matematikteki görsel örnekler tablo gibidir, çünkü anlatılmak istenen birçok şey bazen tek bir görsel örnekle anlatılabilir"

"Matematikteki görsel örnekler grafik çizimleri gibidir, çünkü bazı şeyleri anlamak zor olabiliyor. Grafikleştirmenin anlamayı kolaylaştırması gibi görsel örnekler de daha iyi anlaşılmayı sağlıyor"

Hatırlamak kolaydır (akılda kalıcıdır): Bu tema altında 22 kod bulunmaktadır. Öğretmen adayları, görsel örneklerin öne çıkan özelliklerinden biri olarak akılda kalıcı olmasını belirtmişlerdir. Bu tema altında verilen metaforlardan bazıları fotoğraf (3), film (2), oyun'dur. Öğretmen adaylarının tamamladıkları cümle örnekleri aşağıdaki gibidir.

“Matematikteki görsel örnekler yağ lekesi gibidir, çünkü daha kalıcıdır, unutulması daha zordur”

"Matematikteki görsel örnekler çimentodaki ayak izi gibidir, çünkü kolay kolay kaybolmaz, kalıcıdır"

"Matematikteki görsel örnekler en sevdiğim kitap gibidir, çünkü konusunu ismini asla unutmam"

Dikkat çekicidir: Bu tema altında 13 kod toplanmıştır. Öğretmen adayları görselliğin en önemli boyutlarından biri olan bu özelliği diğer özelliklere göre daha az vurgulamışlardır. Bu tema altında verilen metaforlardan bazıları gökkuşağı (2), havai fişek'tir. Bu metaforların örnek cümleleri ise;

“Matematikteki görsel örnekler havai fişek gibidir, çünkü öğrencinin öğrencilerin dikkatini çeker"

"Matematikteki görsel örnekler gökkuşağı gibidir, çünkü ilgi çekicidir"

"Matematikteki görsel örnekler çiçek gibidir, çünkü ilgi çekici ve rengârenktir"

Matematiğe çeşitlilik ve farklı bakış açısı katar: Bu tema altında 10 kod toplanmıştır. Öğretmen adayları bu şekilde verilen örneklerin matematik içinde farklı bir bakış açısı oluşturacağını düşünmektedir. Bu temada kullanılan metaforlardan bazıları aşağıdaki gibidir.

“Matematikteki görsel örnekler orman gibidir, çünkü içinde birçok çeşitlilik bulunur”

"Matematikteki görsel örnekler doğa gibidir, çünkü içinde bir sürü canlı bulundurur" 
“Matematikteki görsel örnekler tablo gibidir, çünkü ona baktığında değişik bakış açıları ortaya çıkar"

Konuyu anlamayı zorlaştırır: Bu tema altında 9 kod toplanmıştır. Görselleştirme ile ilgili literatür incelendiğinde görsel düşünmenin en çok eleştirilen özelliklerinden biri yanıltıcı olması, sınırlı bilgiye izin vermesi ve dolayısıyla konuyu anlamayı zorlaştırmasıdır. Buna rağmen görsel örneklerin bu özelliği sadece dokuz metafor ile ortaya çıkmıştır. Bu tema altında toplanan metaforlara ilişkin örnek cümleler aşağıdaki gibidir.

“Matematikteki görsel örnekler dalga gibidir, çünkü sonsuz sayıda dalga varken biz sadece sınırlı bir alandaki dalgalara bakarı"

“Matematikteki görsel örnekler rüya gibidir, çünkü rüyanın sonunu bazen göremeyiz, görsel örneklerde görmek istediğimiz şeyi her zaman göstermez"

"Matematikteki görsel örnekler tablo gibidir, çünkü farklı şekillerde yorumlanabilirler"

11 metafor ise herhangi bir tema altına yerleştirilememiştir.

Tablo 1

Görsel Örneklerle ilgili Oluşturulan Metaforlar

\begin{tabular}{|c|c|c|}
\hline & Temalar & Metaforlar \\
\hline \multirow{8}{*}{$\begin{array}{l}\text { Görsel } \\
\text { örnekler }\end{array}$} & $\begin{array}{l}\text { Soyut kavramları } \\
\text { somutlaştırır }\end{array}$ & $\begin{array}{l}\text { Fotoğraf, ışık, günlük hayat, doğa, resim, dokunmak, model, harita, } \\
\text { simülasyon, animasyon, kamu spotu, çikolata, deney, tiyatro, meyve, } \\
\text { abaküs, ilaç, psikolog, süpermen, kavram haritası, büyüteç, gözlük, } \\
\text { anahtar, ipucu, grafik, rüya, uyarlama film, duyu organı, puzzle, } \\
\text { dürbün, hava, yemeğin tuzu, gün doğuşu, el feneri, rahatlatıcı, } \\
\text { makine, hatırlatma, ağaçtaki elma, lego, tasvir }\end{array}$ \\
\hline & $\begin{array}{l}\text { Matematiği zevkli } \\
\text { hale getirir }\end{array}$ & $\begin{array}{l}\text { Şeker, örüntü, ekmek, kar yağması, ağaçtaki meyve, puzzle, nefes } \\
\text { almak, renkler, maç yapmak, nutella, yemeğin tuzu, makyaj, } \\
\text { oyuncak, kurabiye, yemeğin baharatı, sessiz sinema, tablo, karnaval, } \\
\text { resim, doğa, manzara, sinema }\end{array}$ \\
\hline & $\begin{array}{l}\text { Konuyu anlamamızı } \\
\text { kolaylaştırır }\end{array}$ & $\begin{array}{l}\text { Bina, sessiz sinema, makyaj yapan kadın, ayna, göz, tablo, pastanın } \\
\text { çileği, ışık vitrindeki, mankenler, balkon, muzlu pasta, tuz, ilaç, su, } \\
\text { grafik çizimi, katalizör, ağaç, yumurta }\end{array}$ \\
\hline & $\begin{array}{l}\text { Hatırlamak kolaydır } \\
\text { (akılda kalıcıdır) }\end{array}$ & $\begin{array}{l}\text { Yağ lekesi, anı, çamur lekesi, tablo, tamamlayıcı, ufo, mutfak robotu, } \\
\text { tasvir, kısa film, fotoğraf, ,çimentodaki ayak izi, en sevdiğim kitap, } \\
\text { hatırlatma, sinema, oyun, model, hayat }\end{array}$ \\
\hline & Dikkat çekicidir & $\begin{array}{l}\text { Gökkuşağı, havai fişek, oyun, puzzle, fotoğraf, süs, resfebe, } \\
\text { infografik, çiçek, muzlu pasta }\end{array}$ \\
\hline & $\begin{array}{l}\text { Matematiğe çeşitlilik } \\
\text { ve farklı bakış açısı }\end{array}$ & Dalga, orman, doğa, ahşap, tablo, lego, pencere, renk, masal \\
\hline & katar & \\
\hline & $\begin{array}{l}\text { Konuyu anlamayı } \\
\text { zorlaştırır }\end{array}$ & Bebek, tablo, erik, rüya, dalga, pasta, kitabın filmi, su \\
\hline
\end{tabular}

\subsection{Cebirsel Örnekler}

Çalışmanın bu bölümünü, öğretmen adaylarının veri toplama aracının ikinci sorusu olan "Matematikteki cebirsel örnekler... gibidir; çünkü..." cümlesini tamamlayarak oluşturdukları verilerin analizi oluşturmaktadır. Öğretmen adaylarının belirtilen cümleyi tamamlamasıyla oluşturulan kodlar yedi tema altında toplanmaktadır.

Anlaşılması zordur/çaba gerektirir: Öğretmen adayları cebirsel örnekleri anlaşılmasının zor olduğunu, anlayabilmek için üzerinde çalışılması ve çaba harcanması gerektiğini vurgulamışlardır. Bu durum kendini bu tema altında toplanan 60 kod ile göstermiştir. Bu tema için kullanılan bazı metaforlar bulmaca (6), düğüm (4), labirent'tir (2). 
"Matematikteki cebirsel örnekler karabasan gibidir, çünkü çoğu zaman anlaşılmaz, anlaşılsa bile bir yerde mutlaka sorun yaşanır."

"Matematikteki cebirsel örnekler labirent gibidir, çünkü doğru yolu bulamazsan çıkışa ulaşamazsın. İnsanı hatırlamaya, bildiklerini yapıp uygulamaya sevk eder"

"Matematikteki cebirsel örnekler zor bir dans figürü gibidir, çünkü bunu yapmak deneyim, beceri, hâkimiyet ve özgüven gerektirir. Cebirsel örnekleri çözmek de böyledir"

Konunun anlaşılmasını/pekiştirilmesini sağlar: Bu tema altında 45 kod toplanmıştır. Katılımcılar tarafından zor ve karmaşık bulunan cebirsel örnekler anlaşıldığı takdirde konunun daha iyi anlaşımasına katkı sağladığı belirtilmiştir. Bu tema altında verilen metaforlara örnek olarak yol levhası (2), el feneri (2), yapboz parçası (2) verilebilir.

“Matematikteki cebirsel örnekler (kıyafete) uygun çanta gibidir, çünkü çantaların kıyafetleri tamamlaması gibi cebirsel örnekler de konuyu tamamlar."

"Matematikteki cebirsel örnekler yapboz parçası gibidir, çünkü cebirsel örnekler olmadan konuyu anlamak mümkün değildir"

"Matematikteki cebirsel örnekler yemeğe atılan son baharat gibidir, çünkü doğru zamanda atılan baharatın yemeği lezzetlendirmesi gibi doğru zamanda verilen cebirsel örnek konuyu anlamayı sağlar"

Matematiğin temelini oluşturur: Bu temada belirtilen metaforlar ile öğretmen adayları cebirsel örneklerin matematiğin temelini oluşturduğunu ve hatta matematiğin olmazsa olmazı olduğunu belirtmişlerdir. Su (7), besin (2) gibi 25 metafordan oluşan bu temayı şekillendiren cümlelerden bazıları aşağıdaki gibidir.

“Matematikteki cebirsel örnekler harfler gibidir, çünkü matematiği öğrenmek için önce cebirsel örnekleri öğrenmek gerekir, okumayı öğrenmek için harfleri öğrenmek gibi"

"Matematikteki cebirsel örnekler iskelet gibidir, çünkü insanı ayakta tutan iskelettir, matematiği matematik yapan cebirsel ifadelerdir"

“Matematikteki cebirsel örnekler zeytin peynir gibidir, çünkü onlarsız kahvaltı yapılmaz, cebirsel ifadeler olmadan matematik olmaz"

Çok çeşitlidir: Öğretmen adayları verilebilecek cebirsel örneklerin çok çeşitli olabileceğini bu nedenle de sayısının fazla olduğunu düşünmektedirler. Bu tema altında 21 metafor vardır. Uzay (3), örümcek ağı, yıldızlar bu temanın metaforlarından bazılardır.

"Matematikteki cebirsel örnekler uzay gibidir, çünkü sonsuz sayıda verilebilir"

"Matematikteki cebirsel örnekler ağaç gibidir, çünkü dallara ayrıldıkça daha da detaylanır"

"Matematikteki cebirsel örnekler yıldızlar gibidir, çünkü uzaktan aynı görünür fakat çok farklıdırlar"

Belirsizdir: Cebirsel ifadeler de bilinmeyenler olması ya da sonucun belirsiz olması gibi özellikleri nedeniyle katılımcılar tarafından kapalı kutu (3), sihirbaz şapkası, karanlık gibi 15 metaforlarla ifade edilmiştir.

"Matematikteki cebirsel örnekler kapalı kutu gibidir, çünkü bilinmeyen vardır. İçini açmadan ne olduğunu anlayamayız."

"Matematikteki cebirsel örnekler sihirbaz şapkası gibidir, çünkü ne çıkacağı belli değildir"

“Matematikteki cebirsel örnekler çalışmadığım sınavdan alacağım not gibidir, çünkü belirsizdir ve endişelendirir"

Eğlencelidir ve somut kavramları soyutlaştır: Bu iki başlık altında sırasıyla yedi ve beş metafor toplanmıştır. Eğlencelidir teması için katılımcılar cebirsel ifadelerle yapılacak dönüşümleri bulmaca veya oyuncak gibi metaforlarla ifade ederken ikinci temada cebirsel örneklerin kavramların soyutlaştırılmasında kullanıldığını ifade etmişlerdir.

“Matematikteki cebirsel örnekler bulmaca gibidir, çünkü çözmeye çalışırız ve eğlencelidir” 
“Matematikteki cebirsel örnekler büyü gibidir, çünkü soyut dünyanın doğrulandığını gösterir her defasında"

"Matematikteki cebirsel örnekler ehliyet gibidir, çünkü uygulamanın teorileştirilmiş halidir"

Bu başlık altında temalaştırılamayan sekiz metafor bulunmaktadır.

Tablo 2

Cebirsel Örneklerle Ilgili Oluşturulan Metaforlar

\begin{tabular}{|c|c|c|}
\hline & Temalar & Metaforlar \\
\hline \multirow{7}{*}{$\begin{array}{l}\text { Cebirsel } \\
\text { örnekler }\end{array}$} & $\begin{array}{l}\text { Anlaşılması } \\
\text { zordur/çaba } \\
\text { gerektirir }\end{array}$ & $\begin{array}{l}\text { Karalanmış kağıt, hayat, ip yumağı, örümcek ağı, akıl, oyuncak, labirent, } \\
\text { dolaşmış ip yumağı, kördüğüm, düğüm, hayattaki zorluklar, enigma, şifre, } \\
\text { elektrik, suya yazılan yazı, hayalet, karabasan, erkekler, bilmece, refleksler, } \\
\text { oyun, atış, bulmaca } \\
\text { Saklambaç, poligonda atış yapmak, para kazanmak, antrenman, } \\
\text { aklımızdaki, düşünceler, alfabe, hesap makinası, kitap okumak, } \\
\text { üniversiteyi kazanmak, pasaport, } \\
\text { harfler, zor bir dans figürü, hayat, kadınlar, makale, şiir, şifre, deniz, } \\
\text { oyunun prova edilmesi, üvey anne, küçük parçalı Lego, puzzle, merdiven, } \\
\text { uzun roman, sudoku }\end{array}$ \\
\hline & $\begin{array}{l}\text { Konunun } \\
\text { anlaşılmasını/ } \\
\text { pekiştirilmesini } \\
\text { sağlar }\end{array}$ & $\begin{array}{l}\text { Yapboz parçası, köprü, kestirme yol, ağaç, yemeğe en son atılan baharat, } \\
\text { eşit kollu terazi, uygun çanta, el feneri, tohum, yaz akşamları gökyüzü, yol } \\
\text { tarifi, gözlük, bulmaca, kalem, tarih, hayaller, ilaç, pratik, ampul, denklem, } \\
\text { navigasyon, güneş, mars, kutu anahtarı, oyunlar, kullanma kılavuzu, } \\
\text { pusula, alıştırma, hesap makinesi, pekiştirici, konunun özü, idman, ağacın } \\
\text { dalları, maket }\end{array}$ \\
\hline & $\begin{array}{l}\text { Matematiğin } \\
\text { temelini } \\
\text { oluşturur }\end{array}$ & $\begin{array}{l}\text { Kolon, temel, hayatın sözlüğü, su, besin, harfler, yemeğin tuzu, iskelet, } \\
\text { zeytin peynir, deniz, nota, baba, atom, teknoloji, araba, şoför, yapboz } \\
\text { parçası, telefonun arama tuşu }\end{array}$ \\
\hline & Çok çeşitlidir & $\begin{array}{l}\text { İnsan hayatı, uzay, değişken, vagon, Arapsaçı, ağaç, kara tahta, ütopya, } \\
\text { gökyüzü, hikâye, örümcek ağı, yıldızlar, sebze çorbası, bukalemun, doğa, } \\
\text { evren, bitkiler, nar, türlü yemeği }\end{array}$ \\
\hline & Belirsizdir & $\begin{array}{l}\text { Dedektiflik yapmak, çilek tadında muz, hesap makinası, abaküs, düş } \\
\text { kurmak, spagetti, karanlık, damla, çalışmadığım sınavdan alacağım not, } \\
\text { yabancı, kutu, sihirbaz şapkası, uzay }\end{array}$ \\
\hline & Eğlencelidir & Bulmaca, oyun, oyuncak \\
\hline & $\begin{array}{l}\text { Somut } \\
\text { kavramları } \\
\text { soyutlaştır }\end{array}$ & Bilim, ehliyet, zekâ oyunları, resim, büyü \\
\hline
\end{tabular}

\section{3 Öğretmenin Verdiği Örnekler}

Çalışmanın bu bölümünü öğretmen adaylarının veri toplama aracının üçüncü sorusu olan "Matematik dersinde öğretmenin verdiği örnekler... gibidir; çünkü..." cümlesini tamamlayarak oluşturdukları verilerin analizi oluşturmaktadır. Öğretmen adaylarının belirtilen cümleyi tamamlamasıyla oluşturulan kodlar altı tema altında toplanmaktadır.

Konunun anlaşılmasını sağlar: Katılımcılar bu tema altında, öğretmenin verdiği örneklerin var olan matematiksel konunun anlaşımasını sağladığını belirtmektedirler. Bu tema altında 69 metafor toplanmaktadır. Diğer temalarla karşılaştırıldığında en çok bu tema atında metafor toplandığı dikkat çekmektedir. Bu temaya verilen metaforlardan bazıları güneş (5), ilaç (4), tercüman'dır (2). Katılımcıların bu temayı oluşturan cümle örneklerinden bazıları şöyledir.

"Matematik dersinde öğretmenin verdiği örnekler ilaç gibidir, çünkü hastayı iyileştiren ilaç gibi konuyu anlamamızı sağlar."

"Matematik dersinde öğretmenin verdiği örnekler asistan gibidir, çünkü konuları anlamaya yardımcı olur" 
“Matematik dersinde öğretmenin verdiği örnekler cankurtaran gibidir, çünkü öğretmenin verdiği örnekler konuyu anlaşılmaz olmaktan kurtarıyor."

Yol gösterir: Katılımcılar, öğretmenin verdiği örneklerin kendi örneklerini oluşturmalarında ve hatalarını fark etmelerinde yol gösterdiğini ya da başka yollar arandığında bu örneklerden faydalandıklarını belirtmişlerdir. Bu tema altında 43 metafor toplanmaktadır. Bunlardan bazıları pusula (9), harita (7), rehber'dir (4). Bu metaforların ifade edildiği cümlelerden bazıları ise şöyledir.

“Matematik dersinde öğretmenin verdiği örnekler model gibidir, çünkü öğretmenin verdiği örnekler model alınarak yeni örnekler bulmaya çalışılır"

"Matematik dersinde öğretmenin verdiği örnekler gemi rotası gibidir, çünkü konu anlamlandırırken bu örneklerin yönelttiği rotaya göre düşünürüz"

"Matematik dersinde öğretmenin verdiği örnekler araba farı gibidir, çünkü konu anlatımı bu örnekler olmadan havada kalır, daha kolay önümüzü görmemizi sağlar."

Konunun yapı taşıdır: Katılımcılar bu örneklerin bir konu için en önemli ve en temel örnekler olduğunu, bu yüzden bunların öğretmen tarafından verilmesi gerektiğini belirtmektedirler. Konunun en önemli noktaları yine bu örneklerde vurgulanmaktadır. Bu tema altında 33 metafor toplanmıştır. Bunlardan bazıları fragman (2), binanın temeli, ana yemek'tir. Katılımcılar metaforlardan bazılarını aşağıdaki şekilde açıklamışlardır.

“Matematik dersinde öğretmenin verdiği örnekler fragman gibidir, çünkü konuyu özetleyerek akılda kalıcı yerleri vurgulayarak göz önüne serer"

"Matematik dersinde öğretmenin verdiği örnekler evin temeli gibidir, çünkü öğretimde kullanılacak en temel örneklerdir"

"Matematik dersinde öğretmenin verdiği örnekler tohumu sulamak gibidir, çünkü tohumun büyümesi için suya ihtiyacı vardır, öğretmen ne kadar konuyu anlatırsa anlatsın, örnek vermediği sürece o konu havada kalır"

Yapılandırılmıştır, çok çeşitlidir ve anlaşılmazdır: Katılımcılara göre bu örneklerin bir diğer özelliği düzenli ve sıralı olmasıdır. Yapılandırılmış olması teması altında 8 metafor bulunmaktadır. Bir diğer tema olarak öğretmenin verdiği örneklerin çok çeşitli olabileceğini katılımcılar yine 8 metaforla belirtmişlerdir. Katılımcılardan 5 tanesi ise öğretmenin verdiği örneklerin anlaşılmaz olabileceğini belirtmişlerdir.

"Matematik dersinde öğretmenin verdiği örnekler plan gibidir, çünkü düzenli ve sıralıdır"

“Matematik dersinde öğretmenin verdiği örnekler durmadan akan su gibidir, çünkü öğretmen tarafından verilebilecek örneklerin sınırı yoktur"

"Matematik dersinde öğretmenin verdiği örnekler üç boyutlu resim gibidir, çünkü bazı öğrenciler öğretmenin verdiği örneği hemen anlar, bazı öğrenciler ise hemen anlamaz, üç boyutlu resimdeki şekli herkes göremez"

14 metafor ise herhangi bir tema altına yerleştirilememiştir.

Tablo 3

Öğretmenin Verdiği Örneklerle ilgili Oluşturulan Metaforlar

\begin{tabular}{lll}
\hline & Temalar & Metaforlar \\
\hline & Konunun & Matematiğin tercümesi, lamba, ışık, ana yemek, güneş, tanıtım, \\
& $\begin{array}{l}\text { anlaşılmasını } \\
\text { sağlar }\end{array}$ & meyve, anahtar, kapı, ütü, ilaç, berrak su, can suyu, asistan, renkler, \\
& gazoz açacağı, figür, ilk öğretici, büyüteç, cankurtaran, hediye, şeker, \\
Öğretmenin & & sihirli değnek, geometrik şekiller, haber, çizgi film, fotoğraf, ilk yardım \\
verdiği & & ekibi, film gösterimi, boyutlar arası geçiş, tohumu sulamak, değerli bir \\
örnekler & taş, soda, sözlük, farklı yerleri gezip görmek, sisin kalkması, tuğla, iğne, \\
& & anahtarlık, nutuk, zincir, vitamin, yiyecek, kılcal damarlar, belgesel, \\
& & ağaç aşısı, bir yudum su, bilmece, su, yürüteç
\end{tabular}




\begin{tabular}{|c|c|}
\hline & $\begin{array}{l}\text { levhaları, denizdeki inci, ışık, harita, ilk adım, basit oyuncaklar, beyin } \\
\text { büyütücü, tabela, araba farı, navigasyon, ilham, model, gemi rotası, } \\
\text { trafik kurallar gökvüzü, anahtar, vol gösterici, teknik direktör }\end{array}$ \\
\hline $\begin{array}{l}\text { Konunun yapı } \\
\text { taşıdır }\end{array}$ & $\begin{array}{l}\text { Binanın temeli, atom, hava, vitamin, mücevher, çatı, tuğla, gen, } \\
\text { papatya yaprakları, binanın temeli, Lego, arabanın arka koltuğunda } \\
\text { oturmak, sudoku, start düdüğü, kırmızı } \\
\text { alet çantası, makarna, abaküs, fragman, yapı taşı, çorba, atasözü, evin } \\
\text { temeli, meyve, kıvılcım, sms, ekmek, ana yemek }\end{array}$ \\
\hline Yapılandırılmıştır & $\begin{array}{l}\text { Mühendislik, dünyanın en zengin insanı, yapboz, uzman tv, plan, } \\
\text { kanun, geometrik şekil, acı biber }\end{array}$ \\
\hline Çok çeşitlidir & $\begin{array}{l}\text { Ormandaki çiçekler, gökkuşağı, yemek, deniz, durmadan akan su, saç } \\
\text { teli, kütüphane, ağaç, }\end{array}$ \\
\hline Anlaşılmazdır & $\begin{array}{l}\text { Kompleks ifadeler, tünel, kriptoloji, üç boyutlu resim, işin içinden } \\
\text { çıkılmaz olay }\end{array}$ \\
\hline
\end{tabular}

\section{4 Öğrencinin verdiği örnekler}

Çalışmanın bu bölümünü öğretmen adaylarının, veri toplama aracının dördüncü sorusu olan "Matematik dersinde öğrencinin verdiği örnekler... gibidir; çünkü..." cümlesini tamamlayarak oluşturdukları verilerin analizi oluşturmaktadır. Katılımcılar bu örnekleri iki boyutta ele almaktadır: Bir öğrencinin kendisinin örnek vermesi veya sınıf arkadaşının örnek vermesi. Bu boyutlar temaların bazılarında belirginleşirken bazılarında ortaya çıkmamıştır. Öğretmen adaylarının belirtilen cümleyi tamamlamasıyla oluşturulan kodlar yedi tema altında toplanmaktadır.

Öğrencinin konuyu öğrenme derecesini gösterir: Katılımcılar öğrencilerin verdikleri örnekleri, doğruluğuna göre bir ayrım yaparak her iki durumda da öğrencinin konuyu anlama derecesinin bir ifadesi olarak değerlendirmişlerdir. Öğretmen adaylarına göre öğrenciler, doğru örnek veriyorsa konuyu anlamış demektir, yanlış örnek veriyorsa öğrenme ile ilgili problemler var demektir. Dolayısıyla bu, bilişsel anlamda bir olgunlaşma göstergesidir. Bu başlık altında verilen metaforlardan bazıları meyve (5), ayna (4), zirve'dir (2). Bu temada 48 metafor örneği verilmiştir. Katılımcıların metaforlarını açıklama şekillerinden bazıları şöyledir.

\footnotetext{
“Matematik dersinde öğrencinin verdiği örnekler zirve gibidir, çünkü öğrencinin öğrendiğini hedefe ulaştığını gösterir"

"Matematik dersinde öğrencinin verdiği örnekler deneme gibidir, çünkü edebiyatta deneme kişisellik içerir. Öğrencinin verdiği örnekler de kişisel ve kendi algılayışlarının ürünüdür"

"Matematik dersinde öğrencinin verdiği örnekler ayna gibidir, çünkü öğrencinin konuyu ne kadar öğrendiğini yansıtır"
}

Öğrencinin anlaması için gereklidir: Bu tema altında 39 metafor bulunmaktadır. Bu tema altında verilen metaforlar daha önce belirtildiği gibi hem bireysel olarak öğrenci boyutunda hem de sınıftaki diğer öğrenciler boyutunda düşünülmüştür. Bir öğrencinin örnek vermesi, kendi öğrenmesiyle birlikte sınıftaki diğer öğrencilerin öğrenmesi için gerekli olduğu belirtilmiştir. Bu tema altında verilen metaforlardan bazıları su (3), yemeğin tuzu (2) şeklindedir. Bu tema altında tamamlan cümlelere örnekleri ise;

\footnotetext{
"Matematik dersinde öğrencinin verdiği örnekler yemeğe atılan baharat gibidir, çünkü aynı seviyede bir kişinin verdiği örnekler, öğrenmemizi daha anlamlı kılıyor, düşüncelerimizi geliştirmemizi sağlıyor"

"Matematik dersinde öğrencinin verdiği örnekler yürümeyi öğrenen bebek adımları gibidir, çünkü yavaştır, kusursuz değildir ancak bu şekilde öğrenebilir" "Matematik dersinde öğrencinin verdiği örnekler yemeğin tuzu gibidir, çünkü öğrencinin öğrencilerin verdiği örnekler konuyu anlamasını sağlar, yani yemeği tamamlar"
} 
Eksiktir/ karışıktır: Katılımcılar oluşturdukları metaforların açıklamalarında, öğrencinin verdiği örneklerin çok temel düzeyde ya da eksik yanları olduğunu bazen de öğrenme gerçekleşmemişse karmaşık olabileceğini belirtmişlerdir. Bu tema altında da hem bireysel hem de sınıf içindeki diğer öğrenciler açısından düşünülen boyut ortaya çıkmaktadır. Çünkü eksik ve karmaşık verilen örneklerin (diğer öğrenciler açısından) gereksiz olduğunu belirten katılımcılar bulunmaktadır. Bu tema altında 34 metafor bulunmaktadır. Bunlardan bazıları malzemeleri eksik kek karışımı, ham karpuz, labirent, çıkmaz yol'dur. Metaforların açıklandığı bazı cümle örnekleri ise aşağıdaki gibidir.

“Matematik dersinde öğrencinin verdiği örnekler defolu kıyafet gibidir, çünkü eksik yanları vardır"

"Matematik dersinde öğrencinin verdiği örnekler sisli hava gibidir, çünkü net değildir, düzelmeye ihtiyacı vardır"

"Matematik dersinde öğrencinin verdiği örnekler denetlenmeden piyasaya sürülen ürün gibidir, çünkü iyi olup olmadığı kesin değildir, bilen biri tarafından onaylanması gerekir"

Çeşitlidir ve farkı bakış açıları sunar: Bu tema altında oluşturulan metaforlarda öğrencilerin verdiği örneklerin çok çeşitli olabileceği ve bunun da farklı bakış açılarına ve yeni örneklere yol açabileceği belirtilmiştir. Bu tema altında 25 metafor bulunmaktadır. Gökkuşağı (2), seçenek, pencere bunlardan bazılarıdır. Bu tema altında bulunan metafor için oluşturulan cümle örnekleri ise şöyledir.

"Matematik dersinde öğrencinin verdiği örnekler evin arka kapısı gibidir, çünkü konuya farklı bakış açılarıyla sunulan örneklerdir"

"Matematik dersinde öğrencinin verdiği örnekler gökkuşağı gibidir, çünkü her öğrencinin farklı renkler gibi farklı düşünce tarzları vardır"

"Matematik dersinde öğrencinin verdiği örnekler ışık gibidir, çünkü hem konuya hem de yeni örneklere yol gösterir"

Öğretmen için dönüttür: Bu tema altında ortaya çıkan metaforlarda katılımcılar, öğrencilerin verdiği örneklerin öğretmen için bir dönüt, öğretmenin anlattıklarının bir yansıması olduğunu belirtmişlerdir. Bu tema altında 14 metafor bulunmaktadır. Bunlardan bazıları ayna, bilgisayar, bumerang'tır. Katılımcılar bu tema altındaki düşüncelerini şu şekilde açıklamışlardır.

"Matematik dersinde öğrencinin verdiği örnekler ayna gibidir, çünkü öğretmenin ne kadar öğrettiğini yansıtır"

"Matematik dersinde öğrencinin verdiği örnekler çocuk gibidir, çünkü çocuğun başarısının ailenin başarııını göstermesi gibi, bu örnekler ne kadar başarılıysa öğretmen de o kadar başarılıdır"

"Matematik dersinde öğrencinin verdiği örnekler alınan mesaj gibidir, çünkü öğretmenin anlattıklarına karşılık öğrencinin verdiği cevaptır"

Kalıcıdır ve dersi zevkli hale getirir: Kalıcıdır teması altında verilen metaforlarda (6) katılımcılar, öğrenciler kendileri örnek verdiğinde bunların daha zor unutulacağını belirtmektedirler. Dersi zevkli hale getirir (6) teması altında ise öğrencinin örnek vermesinin dersi zevkli hale getiren unsurlardan biri olduğu vurgulanmıştır. Bu temalar altında verilen metaforlardan bazıları çivi yazısı, nakarat, yemeğin tuzu, muz'dur. Katılımcıların metaforlarını açıklama şekillerinden bazıları ise aşağıdaki gibidir.

"Matematik dersinde öğrencinin verdiği örnekler çivi yazısı gibidir, çünkü kolay kolay unutulmaz çünkü kendi ürettiğimiz düşünceler kalıcıdır"

"Matematik dersinde öğrencinin verdiği örnekler nakarat gibidir, çünkü en çok onlar hatırlanır" "Matematik dersinde öğrencinin verdiği örnekler muz gibidir, çünkü çok tatlı ve güzeldir. Dersi zevkli hale getirir" 
Bu başlık altında temalaştıılamayan dokuz metafor bulunmaktadır.

Tablo 4

Öğrencinin Verdiği Örneklerle ilgili Oluşturulan Metaforlar

\begin{tabular}{|c|c|c|}
\hline & Temalar & Metaforlar \\
\hline \multirow{10}{*}{$\begin{array}{l}\text { Öğrencinin } \\
\text { verdiği } \\
\text { örnekler }\end{array}$} & Öğrencinin & Ayna, sınav, meyve, yemek sonrası tatlı, dondurma, tatlı sonrası oluşan \\
\hline & $\begin{array}{l}\text { konuyu } \\
\text { öğrenme } \\
\text { derecesini } \\
\text { gösterir }\end{array}$ & $\begin{array}{l}\text { gülümseme, karpuz, oksijen, espriye verilen tepki, cevap anahtarı, eko, } \\
\text { yeni bir tarif hazırlamak, tiyatro, özet, çikolatalı süt, cila, bal, ışık, anahtar, } \\
\text { aile, sınav kâğıdı, yürümeyi öğrenen, bebek, deneme, gol atmak, } \\
\text { sayılabilir nesneler, fotoğraf, asistan, roman, zirve, cevap, deney } \\
\text { numunesi, birikmiş para, değerlendirme, pencere, ilaç, serap }\end{array}$ \\
\hline & $\begin{array}{l}\text { Öğrencinin } \\
\text { anlaması için } \\
\text { gereklidir }\end{array}$ & $\begin{array}{l}\text { Altın, noktalama işareti, su, güneş, benzin, çimento, olgunlaşmamış } \\
\text { meyve, yemeğin tuzu, somut, gösterge, köprü, alfabe, soru, serap, } \\
\text { detaylar, yemek, çırpınış, harç, bilmece yanıtı, boya astarı, çocuk, alev, } \\
\text { yapıştırıcı, bebek adımları, film müziği, su damlası, tamamlayıcı, puzzle } \\
\text { parçaları, el feneri, yemeğin baharatı, kurallar, tohum, tanılayıcı test, } \\
\text { hava, başlangıç yemeği, tuğla, binanın üst katları }\end{array}$ \\
\hline & Eksiktir/ & Domates, bahçedeki çiçekler, çıkmaz yol, tatlı, bebek konuşması, ham \\
\hline & karışıktır & $\begin{array}{l}\text { karpuz, şeker, tohum, olgunlaşmamış meyve, kuşak farkı, soğanın cücüğü, } \\
\text { yabancı dil, mikser, labirent }\end{array}$ \\
\hline & & $\begin{array}{l}\text { defolu kıyafet, kavrulmuş kestane, tuzlu baklava, kitaptaki dikkat notları, } \\
\text { sisli hava, halüsinasyon, denetlenmeden piyasaya sürülen ürün, yaprak, } \\
\text { sineklik, malzemeleri eksik kek karışımı, su damlası, süzgeç, oyun hamuru, } \\
\text { kargaşa, reklam, cetveldeki delik, arama, motoru, oyun, geçmiş ve şimdiki } \\
\text { yaşantıları, damdan düşen kedi }\end{array}$ \\
\hline & $\begin{array}{l}\text { Çeşitlidir ve } \\
\text { farkı bakış } \\
\text { açıları sunar }\end{array}$ & $\begin{array}{l}\text { Gökkuşağı, kitap, gökyüzü, deniz, kazı kazan, pencere, hayat, renkli taşlar, } \\
\text { teknoloji, evin arka kapısı, seçenek, icat etmek, renkli kalem, ağacın } \\
\text { dalları, dünya, hayatın kendisi, fidan }\end{array}$ \\
\hline & $\begin{array}{l}\text { Öğretmen için } \\
\text { dönüttür }\end{array}$ & $\begin{array}{l}\text { Bilgisayar, ayna, sıradan hayat, evcilik oyunu, bumerang, gözlük, fotokopi, } \\
\text { tost makinası, alınan mesaj, kan, şeker, çikolata }\end{array}$ \\
\hline & Kalıcıdır & Yazı, anı, yol haritası, oksijen, nakarat, çivi yazısı \\
\hline & $\begin{array}{l}\text { Dersi zevkli } \\
\text { hale getirir }\end{array}$ & Örüntüler, bulmaca, muz, tuz, su \\
\hline
\end{tabular}

Öğretmen adaylarının seçtikleri metaforlar ile sınıf düzeyleri arasındaki ilişki Ki-kare testi ile incelenmiştir. Öğretmen adaylarının görsel örnekler, cebirsel örnekler, öğretmenin verdiği örnekler ve öğrenciler tarafından oluşturulan örnekler ile ilgili oluşturdukları metaforlar ve sınıf düzeyleri arasında anlamlı ilişki bulunamamıştır ( $p=0.171, p=0.177, p=0.565, p=0.374)$.

\subsection{Görüşmelerden Elde Edilen Bulgular}

Daha önce belirtildiği gibi yapılan kodlamaların ve oluşturulan temaların doğruluğu belirlemek için 11 katılımcı ile görüşme yapılmıştır. Görüşmeye katılan katılımcıların tamamı oluşturdukları metaforların bulundukları temaları doğrulamışlardır. Bunlara ek olarak görüşme yapılan katılımcılara, veri toplama aracında bulunan son iki cümleyle bağlantılı olarak, örneklerin öğretmen adayları tarafından algılanmasını ortaya çıkarmak ve derinlemesine veri elde etmek amacıyla iki soru daha yöneltilmiştir:

1. Bir öğretmen adayı olarak matematiksel örnekleri sınıf içinde nasıl ve hangi amaçla kullanmayı düşünürsünüz?

2. Öğretmenler ve öğrenciler tarafından verilen örneklerin kavramsal anlamaya ve kalıcılığa olan etkisi nedir?

Görüşme verilerinden elde edilen ilk bulgu öğretmen adaylarının örnekleri algılamalarının çoğunlukla, daha önce alan yazında kullanılan sınıflamalardan biri olan bir 
kavramın örneği ya da bir prosedürün örneği şeklinde olduğu gözlenmiştir. Aşağıdaki alıntılarda bu durum gözlenebilmektedir.

B: Mesela bir örnek sunarım. Bir problem. Ve bu problemi öğrettiklerimizi ışı̆ında çözmelerini isterim.

M2: Öğrencinin verdiği örnekten konuyu ne kadar anladığını ya da o kavramı nereye yerleştirdiğini, zihninde nerede durduğunu öğrenmiş oluyoruz.

E: Kendi alanım açısından düşündüğüm zaman mesela en başta konuyu anlatırken şu nedir, açıortay nedir gibi fikir üretmelerini sağlayabilirim ama matematikte daha çok öğretmenin soru yazması [prosedürel örnek] gerekiyormuş gibi geliyor bana... Yani daha çok öğretmenin örnek vermesi gerekiyormuş gibi geliyor.

Öğretmen adaylarının örnekleri sınıf içinde kullanma şekilleri, öğretmen ve öğrenci, konu hakkında öğrencinin sahip olduğu bilgi miktarı, kullanılan yöntem, sınıfta kullanma zamanı boyutlarında değişmektedir. Bu boyutlar bazı özellikleriyle öne çıkmakla birlikte her bir boyutun diğer boyutla kesiştiği alanlar olduğunu söylemek mümkündür. Öğretmen adayları kendi derslerinde örnekleri hem kendilerinin vereceklerini hem de öğrencilerinden isteyeceklerini belirlemişlerdir. Öğrencilerin örnekleriyle ilgili olarak vurguladıkları en önemli nokta, öğretmenin anında dönüt verilmesi gerektiğidir. Öğrencinin verdiği örnek doğruysa onaylanacak, yanlışsa düzeltilecek ve dolayısıyla olası kavram yanılgılarının önüne geçilecektir.

G: Öğrenci örnek verirken aklına takılan bir nokta varsa mesela o noktayı daha iyi irdelemesi açısından önemli oluyor. Öğretmen örnek verirken bu olmuyor mu? Öğretmeni ne kadar etkin dinlediğine bağlı. Öğretmen çok iyi örnekler veriyor olabilir ama eğer çocuk örnek vermezse iyi anlayıp anlamadığını bilemiyorsunuz. Dönüt düzeltme meselesi var. Aksi takdirde öğretmen bunu gerçekleştiremez. Çocukların örnek vermesi kavram yanılgısı (düzeltilmesi) açısından çok önemli...

M1: Öğrenciler kendi örneklerinde nasıl anladığını yansıtacak öğretmenlerde bunu görüp buna göre dönüt verecek.

Öğretmen adayları için örneklerin sınıf içinde kullanımını etkileyen faktörlerden biri de konu hakkında öğrencinin sahip olduğu bilgidir. Öğretmenin örnek vermesinin nedenleri soyut kavramları somutlaştırmak ve konunun daha iyi anlaşılmasını sağlamaktır. Fakat konu, öğrenci tarafından biliniyorsa, konu hakkında öğrencinin hazırbulunuşluğu/önbilgileri ya da konunun anlaşılıp anlaşılmadığı kontrol edilmek isteniyorsa öğrenciden örnek istenmektedir.

N: Somut olarak aklında canlanabilmesi için... Çünkü matematik biraz daha soyut. Bilişsel süreçler zamanla gelişiyor. Biz lise öğretmeni olacağı. Belki bu süreçler biraz daha gelişmiş. Ama ne kadar çok örnek verirsem, ne kadar somut olursa o kadar kalıcı olur. Bende öyle oluyordu çünkü...

Z: Sonuçta matematik soyut şeylerden oluşuyor. O soyut kavramları somutlaştırmak için örnek verebilirim. Kazanıma göre de değişir. Soracağım soru önceki kazanımları ile ilgiliyse ders başında isterim. Ama ben soyut bir kavramı anlattım. Anlattıklarımı ölçmek yani öğrencinin anlayıp anlamadığını kontrol etmek amacıyla da örnek isteyebilirim.

Kullanılan yöntem de örneklerin sınıf içinde kullanımını etkilemektedir. Katılımcılardan biri bu durumu şu şekilde ifade etmiştir.

C: Biraz seçtiğimiz yöntemle alakalalı bence. Seçtiğimiz yöntem düz anlatımsa, kavramları öğretmek anlamında örnekler veririz. Seçtiğimiz örnekler daha çok buluşla ilgiliyse öğrencilere bir yanlış bir doğru örnek vererek kavramalarını daha iyi sağlayabiliriz.

Öğretmen adayları bir konuyu anlatırken ilk örnekleri kendileri vermeyi tercih ederken konunun ilerleyen aşamalarında öğrenciden örnek istemenin daha doğru bir strateji olacağını düşünmektedir. Örneğin konu başında verilen örnekler daha çok dikkat çekmek ve güdülemek amacıyla kullanılmak istenirken ilerleyen aşamalarda konunun daha iyi anlaşıması 
hedeflenmektedir. Bu nedenle ilk örneklerin öğretmen tarafından verilmesi tercih edilmektedir.

$\mathrm{H}$ : İlk giriş kısmında ben örnek veririm daha sonra onların bulmasını isterim. illk örnekleri öğretmen vermeli sonraki örnekleri ise öğrenci vermelidir.

Öğrenilenlerin kalıcılığı anlamında katılımcıların tamamı öğrencilerin verdikleri örneklerin daha yararlı olduğunu düşünürken, kavramsal anlamanın sağlanması anlamında öğretmenin verdiği örneklerin daha etkili olduğunu düşünmektedir.

Ş: Konuyu öğrenciye kavratmak için örnek verilmelidir. Özellikler öğrencilerinin yaşamına uygun örnekler verildiğinde daha iyi anlaşılacaktır.

G: Çocuk mesela kendi örneğini verdiği zaman daha kalııı oluyor. Mesela ben kendi derslerime çalışırken günlük hayatımdan çağrışımlar yapıyorum. Kendi kendime örnekler veriyorum. Bu bile benim öğrenmemi etkiliyor.

\section{SONUÇ, TARTIŞMA VE ÖNERILER}

Bu çalışmanın amacı öğretmen adaylarının matematiksel örnekler kapsamında sahip oldukları metaforları belirleyerek sınıfta, örnek kullanımlarına ilişkin algılarını ortaya çıkarmaktır. Bu amaçla öğretmen adaylarının, sınıfta kullanılabilecek iki örnek türü olan görsel ve cebirsel örneklerle beraber, öğretmen ve öğrenciler tarafından verilen örnekler hakkında toplamda dört cümleyi tamamlamaları istenmiştir. Tamamlanan cümleler incelendiğinde, öğretmen adaylarının yanıtlarını iki bakış açısıyla -öğretmen adayı ve öğrenci- verdikleri söylenebilir.

Görsel örneklerin öğretmen adayları tarafından vurgulanan özellikleri akademik ve akademik olmayan iki kategori altında toplanabilir. Görsel örnekler, soyut kavramları somutlaştırarak, öğrenmedeki kalıcılığı arttırarak, kimi durumda anlamayı kolaylaştırıp kimi durumda zorlaştırarak ve farklı bakış açıları sunarak akademik anlamda katkı sağlamaktadır. Görselleştirmenin eleştirilen bir boyutu olan ve kimi zaman anlamayı zorlaştırması olarak ifade edilen tema, öğretmen adayları tarafından diğer temalarla karşılaştırıldığında çok fazla vurgulanmamış ve olumsuz tek tema olarak ortaya çıkmıştır. Akademik olmayan boyutta ise matematiği renklendiren, ilgi ve dikkat çeken özellikleri ortaya çıkmıştır. Buna karşılık cebirsel örneklerin çoğunlukla konunun anlaşılmasına olan katkısı ve bilişsel anlamda oluşturduğu yüke vurgu yapılmıştır. Cebirsel örnekler, her ne kadar öğretmen adayları tarafından anlaşılması zor olması ve çaba gerektirmesi yönleriyle ifade edilmiş olsa da anlaşıldığında, konunun pekiştirilmesini sağladığı, matematiğin yapı taşı olduğu gibi özellikleri en çok vurgu yapılan ikinci özellik olmuştur. Görsel örneklerin aksine cebirsel örneklerin daha çok akademik özelliklerine değinilmiş, katılımcıların çok azı tarafından eğlenceli olduğu ifade edilmiştir.

Öğretmen tarafından verilen örneklerin, öğretmen adayları tarafından en çok vurgulanan özelliği matematiksel bir konunun anlaşılmasına en çok katkı sağlayan örnek türü olmasıdır. Bu örnek türü aynı zamanda öğrencilerin kendi örneklerini oluşturmasında onlara yol göstermesi ve rehberlik yapması açısından oldukça önemli bir role sahiptir. Öğretmen adaylarına göre bu örneklerin bir diğer özelliğinin de yapılandırılmış olmasıdır. Bills vd. (2006) pedagojik anlamda yararlı örneklerin iki temel özelliğinden bahsetmektedir. Bunlardan ilki, öğretilmek istenen özelliklere, hedef kitlenin yani öğrencilerin dikkatini kolayca çekebilecek kadar şeffaf olması, ikinci özellik ise genelleştirmeyi teşvik etmesidir yani gösterilen durumun bir örneğini oluşturmak için önemli özelliklerin vurgulanması aynı zamanda keyfi ve değiştirilebilir özelliklere de işaret etmesidir. Katılımcılar, öğretmen tarafından verilen örneklerin en önemli noktaları vurguladığını, belli bir düzende verildiğini belirterek, aslında literatürde verilen özelliklerle benzer düşüncelere sahip olduklarını göstermektedirler. Katılımcılardan bazıları ise öğrenci kimliğiyle cevap vererek öğretmen tarafından verilen 
örneklerin anlaşılmaz olabileceğini ifade etmişlerdir. Öğrencilerin verdiği örneklerin en önemli özelliği ise kendi öğrenmeleri hakkında hem kendilerine hem de öğretmene bilgi sağlamasıdır. Dolayısıyla bu durum öğrenci tarafından verilen örneklerin, hem bir ölçme aracı olarak hem de bir iletişim aracı olarak düşünülmesine neden olmuştur. Bu sonuç, Leihhart'ın (2001) çalışmasında belirttiği gibi örneklerin öğretmen ve öğrenci arasında bir iletişim aracı rolü oluşturmasını doğrular niteliktedir. Öğrencinin verdiği örnekler sayesinde öğretmen, öğrenmedeki eksiklikler konusunda fikir sahibi olabilmektedir. Katılımcılardan bazıları, öğretim yöntemi ve öğretimsel beceriler açısından öğrenci örneklerinin, öğretmenin kendi için de bir dönüt olduğunu düşünmektedir. Bu yüzden ayna metaforu gibi bazı metaforlar bazen öğrencinin öğrendiklerinin yansıması olarak kullanılırken bazen de öğretmene dönüt oluşturması anlamında kullanılmıştır. Öğrenci örneklerinin belirtilen diğer özellikleri ise eksikliklerinin var olması, dersi dinamik hale getirmesi ve monotonluktan kurtarmasıdır.

Öğretmen adaylarının metaforlarının oluşturdukları temalar ve sınıf düzeyleri arasında anlamlı bir ilişki bulunamamıştır. Aslında örneklere yönelik algıların sınıf düzeyi arttıkça daha sofistike özellikler kazanması ve temalara dağılımın bu yönde olması beklenen bir bulgu olmasına rağmen, bu değişkenler arasında anlamlı ilişki ortaya çıkmamıştır. Daha geniş örneklemlerle yapılacak çalışmalar bu tür bulguların ortaya çıkmasında etkili olabilir.

Öğretmen adaylarıyla yapılan görüşmelerde ise örnek kavramı katılımcıların çoğu tarafından bir kavramın ya da bir prosedürün örneği olarak düşünüldüğü gözlenmiştir. Çok az katılımcı tarafından ters örnek ve örnek olmayan durum, örnek türü olarak belirtilmiştir. Oysa özellikle ters örnek, özel bir ifadenin neden doğru olmadığına ilişkin iç görü oluşturup açıklama sunmasının yanı sıra, aynı ifade için farklı ters örneklerin bulunması için fikir vermesi (Peled ve Zaslavsky, 1997) nedeniyle, öğretimsel gücü oldukça yüksektir. Bunun yanında öğretmen adaylarının matematiksel örnek algılarının çoğunlukla belli prosedürlerin uygulandığı problemler, sorular ya da alıştırmalardan oluştuğu ve bu tür örnekleri çoğunlukla kendilerinin vermeyi planlandıkları ortaya çıkmıştır. Öğrencilerden istenecek örneklerin ise çoğunlukla bir kavramın örneğine yönelik olacağı ortaya çıkmış, daha karmaşık bilişsel süreçler gerektirecek örnek üretme aktivitelerine değinmemişlerdir. Bu nedenle öğretmen adaylarının örnek kullanımlarının geleneksel düzeyde kaldığı söylenebilir.

Öğretmen adaylarının, örneklerin sınıf içinde kullanımına yönelik algıları incelendiğinde çoğunlukla öğrenilen prosedürlerin uygulanmasına ilişkin örnek kullanmayı düşündükleri görülmektedir. Örneklerin kullanımına yönelik araştırmalar incelendiğinde (Zodik ve Zaslavsky, 2009; Dahlberg ve Housmann, 1997; Watson ve Mason 2005) genelleme soyutlama gibi matematiksel becerilerin gelişmesine sağladıkları katkı ve bir kavramın öğrenildiği ilk aşamalardaki rolleri ile örnekler pedagojik anlamda önemli araçlardır. Ancak öğretmen adaylarının bu araçların kullanımı ile ilgili bilgileri çoğunlukla öğretmenlerini gözleyerek edindikleri formal olmayan öğrenmeler ya da kendi öğrenmeleri ile sahip olduğu bilgilerden oluştuğu ortaya çıkmıştır. Öğrencilerin kendi deneyimlerinden yola çıkarak oluşturduğu varsayımlar Aubry'nin (2009) çalışmasında belirttiği gibi olaylar hakkındaki düşüncelerimizin, daha önce yaşadığımız deneyimler etkisiyle şekillenen beynimizden geldiğini ve bu çalışmanın varsayımlarından biri olan, öğretmen adaylarının örnekler hakkındaki algılarının gelecekteki öğretim faaliyetlerini etkileme potansiyeline sahip olduğu savını doğrulamaktadır. Öğretmen adaylarının pedagojik anlamda güçlü araçlar olan örnekleri daha iyi kullanabilmelerine yönelik öğretim programlarına eklenecek içerik ve dersler, matematiksel düşünme becerilerini geliştirecek hatta düşünme becerileri daha iyi öğrencilerin yetişmesine neden olacaktır. 


\section{KAYNAKLAR}

Abdul-Rahman, S. (2005). Learning with examples and students' understanding of integration. In A. Rogerson (Ed.), Proceedings of the Eighth International Conference of Mathematics Education into the 21st Century Project on "Reform, Revolution and Paradigm Shifts in Mathematics Education. Johor Bahru: UTM.

Aubry, M. (2009). Metaphors in mathematics: Introduction and the case of clgebraic geometry. Available SSRN: http://ssrn.com/abstract=1478871 or http://dx.doi.org/10.2139/ssrn.1478871

Bills, L., Dreyfus, T., Mason, J. Tsamir, P. Watson, A. \& Zaslavsky, O. (2006). Example generating in mathematics education, In J. Novotná, H. Moraová, M. Krátká, \& N. Stehliková (Eds.), Proceedings of the 30th Annual Conference of the International Group for the Psychology of Mathematics Education (Vol. 1, pp. 126-154). Prague: Czech Republic.

Bullough, R. (1991). Exploring personal teaching metaphors in preservice teacher education. Journal of Teacher Education, 42(1), 43-51.

Cerit, Y. (2006). Öğrenci, öğretmen ve yöneticilerin okul kavramıyla ilgili metaforlara ilişkin görüşleri. Kuram ve Uygulamada Eğitim Bilimleri, 6(3), 669-699.

Chapman, O. (1997). Metaphors in the teaching of mathematical problem solving. Educational Studies in Mathematics, 32(3), 201-228.

Creswell, J.W. (2008). Educational research planning, conducting, and evaluating qualitative research (3rd Ed.). NJ: Pearson Education.

Dahlberg, R. P. \& Housman, D. L. (1997). Facilitating learning events through example generation. Educational Studies in Mathematics, 33, 283-299.

Font, V., Bolite, J., \& Acevedo, J. (2010). Metaphors in mathematics classrooms: analyzing the dynamic process of teaching and learning of graph functions. Educational Studies in Mathematics, 75,131-152.

Font, V., Godino, J. D., Planas, N. \& Acevedo, J. I. (2010). The object metaphor and synecdoche in mathematics classroom discourse. For the Learning of Mathematics, 30(1), 15-19.

Goldenberg, P. \& Mason, J. (2008). Shedding light on and with example spaces. Educational Studies in Mathematics, 69, 183-194.

Güler, G., Akgün, L., Öçal, M. F., \& Doruk, M. (2011). Pre-service mathematics teachers' metaphors about mathematics concept. Journal of Research in Education and Teaching, $1(2), 25-29$.

Ju, M.K. \& Kwon, O.N. (2004). Analysis of students' use of metaphor: The case of an RMEbased differential equations course. Journal of the Korea Society of Mathematical Education, 8(1), 19-30.

Lakoff, G. \& Johnson, M. (2015). Metaforlar, hayat, anlam ve dil. (Çev. Gökhan Yavuz Demir). İstanbul: İthaki Yayınları. (Özgün çalışma, 1980).

Leavy, A.M., McSorley, F.A. \& Bote, L.A. (2007). An Examination of what metaphor construction reveals about the evolution of preservice teachers' beliefs about teaching and learning. Teaching and Teacher Education, 23, 1217-1233. 
Leinhardt, G. (2001). Instructional explanations: A commonplace for teaching and location for contrast. In V. Richardson (Ed.). Handbook of research on teaching (4th ed., pp. 333357). Washington, DC, USA: American Educational Research Association.

Martinez, M., Sauleda, N., \& Huber, G. (2001). Metaphors as blueprints of thinking aboutteaching and learning. Teaching and Teacher Education, 17, 965-977.

Michener, E. (1978). Understanding mathematics. Cognitive Science, 2, 361-383.

Miles, M.B., \& Huberman, M. (1994) Qualitative Data Analysis: An expanded sourcebook. (2.baskı)Tousand Oaks, CA: Sage.

Moser, K. S. (2000). Metaphor analysis in psychology - method, theory, and fields of application. Forum: Qualitative Social Research, 1(2). Article 21.

Neuendorf, K. A. (2002). The content analysis guidebook. Thousand Oaks, CA: Sage.

Peled, I., \& Zaslavsky, O. (1997). Counter-examples that (only) prove and counter-examples that (also) explain. FOCUS on Learning Problems in Mathematics, 19(3), 49-61.

Saban, A. (2004). Prospective classroom teachers' metaphorical images of selves and comparing them to those they have of their elementary and cooperating teachers. International Journal of Educational Development, 24, 617-635.

Saban, A., Koçbeker, B. N. ve Saban, A. (2006). Öğretmen adaylarının öğretmen kavramına ilişkin algılarının metafor analizi yoluyla incelenmesi. Kuram ve Uygulamada Eğitim Bilimleri, 6(2), 461-522.

Saban, A. (2009). Öğretmen adaylarının öğrenci kavramına ilişkin sahip oldukları zihinsel imgeler. Türk Eğitim Bilimleri Dergisi, 7(2), 281-326.

Saglam, Y. (2014). Visual preferences and teaching anxiety of preservice mathematics teachers. Proc. Soc. Behav. Sci., 141,1270-1274.

Skemp, R. R. (1971). The psychology of learning mathematics. Harmondsworth, UK: Penguin Books, Ltd.

Thompson, A. G. (1992). Teachers' beliefs and conceptions: A synthesis of the research. In D. A. Grouws (Ed.), Handbook of research on mathematics teaching and learning (pp. 127146). Reston, VA: National Council of Teachers of Mathematics.

Uygun, T., Gökkurt, B., Usta, N. (2016). Üniversite öğrencilerinin matematik problemine ilişkin algılarının metafor yoluyla analiz edilmesi. Bartın Üniversitesi Eğitim Fakültesi Dergisi, $5(2), 536-556$.

Watson, A., \& Mason, J. (2005). Mathematics as a constructive activity: Learners generating examples. Mahwah, NJ: Erlbaum.

Yıldırım, A., \& Şimşek, H. (2005). Sosyal bilimlerde nitel araştırma yöntemleri. (5. Baskı). Ankara: Seçkin Yayıncılık.

Zaslavsky, O., \& Zodik, I. (2007). Mathematics teachers' choices of examples that potentially support or impede learning. Research in Mathematics Education, 9, 143-155. 
Zaslavsky, O. (2010). The explanatory power of examples in mathematics: challenges for teaching. In Stein, M. K. and Kucan, L. (Eds.). Instructional Explanations in the Disciplines (pp. 107-128). Springer.

Zazkis, R., \& Leikin, R. (2008). Exemplifying definitions: A case of a square. Educational Studies in Mathematics, 69(2), 131-148.

Zodik, I., \& Zaslavsky, O. (2009). Teachers' treatment of examples as learning opportunities. In Tzekaki, M., Kaldrimidou, M., \& Sakonidis, C. (Eds.). Proceedings of the 33rd Conference of the International Group for the Psychology of Mathematics Education, v.5, pp. 425432.Thessaloniki, Greece: PME. 


\section{SUMMARY}

Examples are indispensable part of educational activities regardless of in which field they are used. Teachers use examples for different purposes. As selection of examples has the potential to facilitate or complicate the learning of students, teachers have challenging responsibilities about choosing examples to design their courses, and they are required to think many features of examples (Zaslavsky \& Zodik, 2007). However, there are a few studies how teachers choose examples or what they should take into account in this process. Besides that, the way of using examples provide information about teachers' mathematical and pedagogical knowledge (Zodik \& Zaslavsky, 2009).

Metaphor can be defined as a strong mental structure, which an individual used to describe an abstract, complex and theoretical phenomenon (Saban, Koçbeker \& Saban, 2006). Like in metaphor 'Mathematics is a ladder' a more abstract concept 'mathematics' was related to a concept that is more concrete. In this relationship, it can be concluded that mathematics is a cumulative branch of science and it can be proceeded to more complex concepts, starting with the most basic ones. The conceptual metaphor theory actually is an attempt to understand how we think and our understanding stems from our experiences and our brain, which is shaped through culture we live in (Aubry, 2009). Because metaphors establish relations between different senses, they are also essential to constitute mathematical concepts (Font, Bolite \& Acevedo, 2010).

The main objective of teacher training programs is to equip teachers with the knowledge and skills required in the field of education. But one of the points that teacher educators should take into account is that prospective teachers are coming to classrooms with different experiences, just like other students. Therefore, prospective teachers' perceptions and experiences should be revealed during the process of building their skills. So the purpose of this study is to investigate preservice teachers' conception of different kinds of examples (visual and algebraic examples in mathematic classes; mathematical examples given by teachers or generated by students). As previously noted in many studies (e.g. Saglam, 2014) affective characteristics, beliefs, experiences, and perceptions have the potential to effect teachers' activities within their classes. Thus, the discovery of such characteristics of teachers will create opportunities for the reorganization of the content of teacher training programs in accordance with nowadays' changing conditions. The participants of the study consist of 190 preservice mathematics teachers. Data collection tool is included four uncompleted sentences in the form of: "Visual examples in mathematics are like..., because..."; "algebraic examples in mathematics are like..., because..."; "Examples given by teacher in mathematics are like..., because..."; "Examples given by students in mathematics are like..., because...". Participants were asked to complete these sentences. Obtained data were analyzed by using content analysis. To ensure the reliability of the data interviews were conducted with 11 of participants, so classification and thematization of metaphors were checked. In addition, through the interviews in-depth information was obtained on perceptions of preservice teachers with respect to mathematical examples.

According to results, preservice teachers have two standpoints by constructing their metaphors: Student and teacher. For visual examples, seven themes revealed: Visual examples concretize abstract concepts, make mathematics fun, facilitate to understand the topic, are easy to remember, are attention grabbing, add to mathematics diversity and different points of view, and make topic difficult to understand. In these sense, visual examples have academic and non-academic role in learning process according to participants. Algebraic examples facilitate and strengthen the understanding, are difficult to understand, are basic for mathematics, are varied, are indefinite, are fun and make concrete concepts abstract. Examples, which were given by teachers facilitate the understanding of mathematical topic, guide, constitute a basis for a topic, are structured, are varied and are incomprehensive. Finally, examples generated by students are indicator of learning level, are essential for understanding, are deficit/tangled, are varied, are feedback for teacher, are long lasting, and make lessons fun.

In interviews, it was observed that preservice teachers' decisions on use of examples in class differ according to teacher and student, readiniess of students, method used in class and period of class time. In addition to that teacher candidates take into account mostly the examples of a procedure or a concept. Very few of the participants were mentioned about counter examples and non-examples, which have strong educational power. It can be concluded that teacher-training programs need additional lessons and contents that can help teacher to use examples in an efficient way. 